\title{
16. NEOGENE PLANKTONIC FORAMINIFERS FROM DSDP LEG 40 SITES 360 AND 362 IN THE SOUTHEASTERN ATLANTIC
}

\author{
D. Graham Jenkins, Department of Geology, University College of Wales, Aberystwyth, Wales
}

\begin{abstract}
From the documentation of the Neogene planktonic foraminifer species from 126 samples of DSDP Leg 40 Sites 360 and 362 in the southeastern Atlantic, a comparison is made of the two sets of faunas within the framework of the established Austral biostratigraphic zonal scheme. A species diversity difference exists between the two sites with a greater species number at Site 362 due to the migration southwards of exotic species which did not reach Site 360 . A strong affinity exists between the faunas of Sites 360 and 362 and those of southeastern Australia and New Zealand, probably due to their similar latitudinal positions and to the circum-Antarctic current connection.
\end{abstract}

\section{INTRODUCTION}

For the convenience of this Neogene report on the planktonic foraminifer faunas of Sites 360 and 362 in the southeastern Atlantic (Figure 1), the base of the Miocene is taken at the initial appearance of Globorotalia kugleri Bolli and the upper Miocene boundary at the initial appearance of Globorotalia margaritae Bolli and Bermudez.

Both sites yielded excellent faunas, and species from the southern Site 360 (lat $30^{\circ} 51^{\prime} \mathrm{S}$, long $18^{\circ} 05^{\prime} \mathrm{E}$ ) have been recorded from the lower Miocene Globigerina woodi connecta Zone through the lower Pliocene Globorotalia puncticulata Zone (Table 1). Similarly, species from the more northern Site 362 (lat $19^{\circ} 45^{\prime} \mathrm{S}$; long $10^{\circ} 32^{\prime} \mathrm{E}$ ) have been recorded from selected samples from the lower Miocene Globoquadrina dehiscens Zone through to the upper Pleistocene to Recent Globorotalia truncatulinoides Zone (Table 2). Thus it is possible to make a direct comparison of the faunas of the two sites for the whole of the Miocene and basal Pliocene, and use this information to elucidate the oceanic conditions in the southeastern Atlantic at this time. A complication is that solution effects at both sites have effectively reduced species diversity in some individual samples.

Significant faunal differences existed between the two sites throughout the Miocene, mainly because of the higher species diversity at the more northern Site 362; only a few species existed at Site 360 , apparently restricted to the relatively cooler southern waters (for example, Globorotalia zealandica Hornibrook in the lower Miocene Globigerinoides trilobus trilobus Zone). Even so, the fauna from Site 362 was never entirely tropical in the Neogene, not only because of the lack of certain species (e.g., Globorotalia fohsi robusta Bolli, Pulleniatina obliquiloculata [Parker and Jones], Globigerinoides fistulosus [Schubert], etc.) but also more

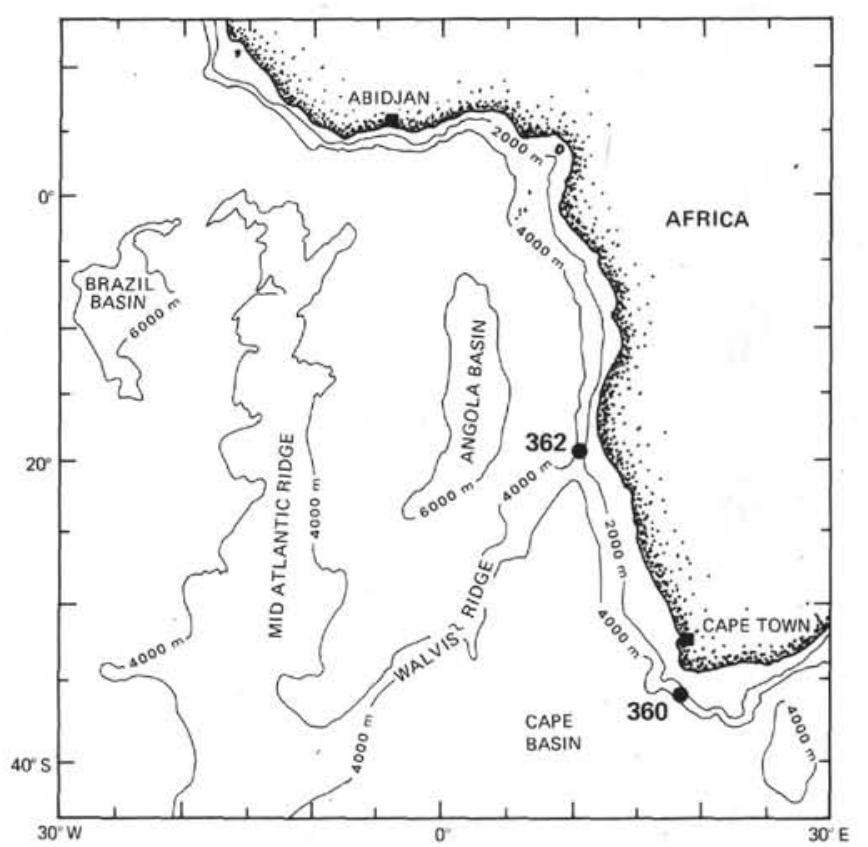

Figure 1. DSDP Leg 40 Sites 360 and 362.

significantly because of the paucity of certain tropical species even when present (e.g., Globigerinatella insueta Cushman and Stainforth, Sphaeroidinella dehiscens [Parker and Jones], and Globoquadrina tripartita [Koch]). Also, the dominant keeled Globorotalia in the middle-upper Miocene was the cooler water Globorotalia miozea Finlay and thereafter in the PliocenePleistocene, keeled Globorotalia are generally absent except for small Globorotalia menardii (d'Orbigny) which was restricted to only the lower part of the Pliocene Globorotalia puncticulata Zone. This interpretation of a progressive cooling is supported by the lack of known tropical species such as Globorotalia 
TABLE 1

Planktonic Foraminiferal Neogene Range Chart: Site 360

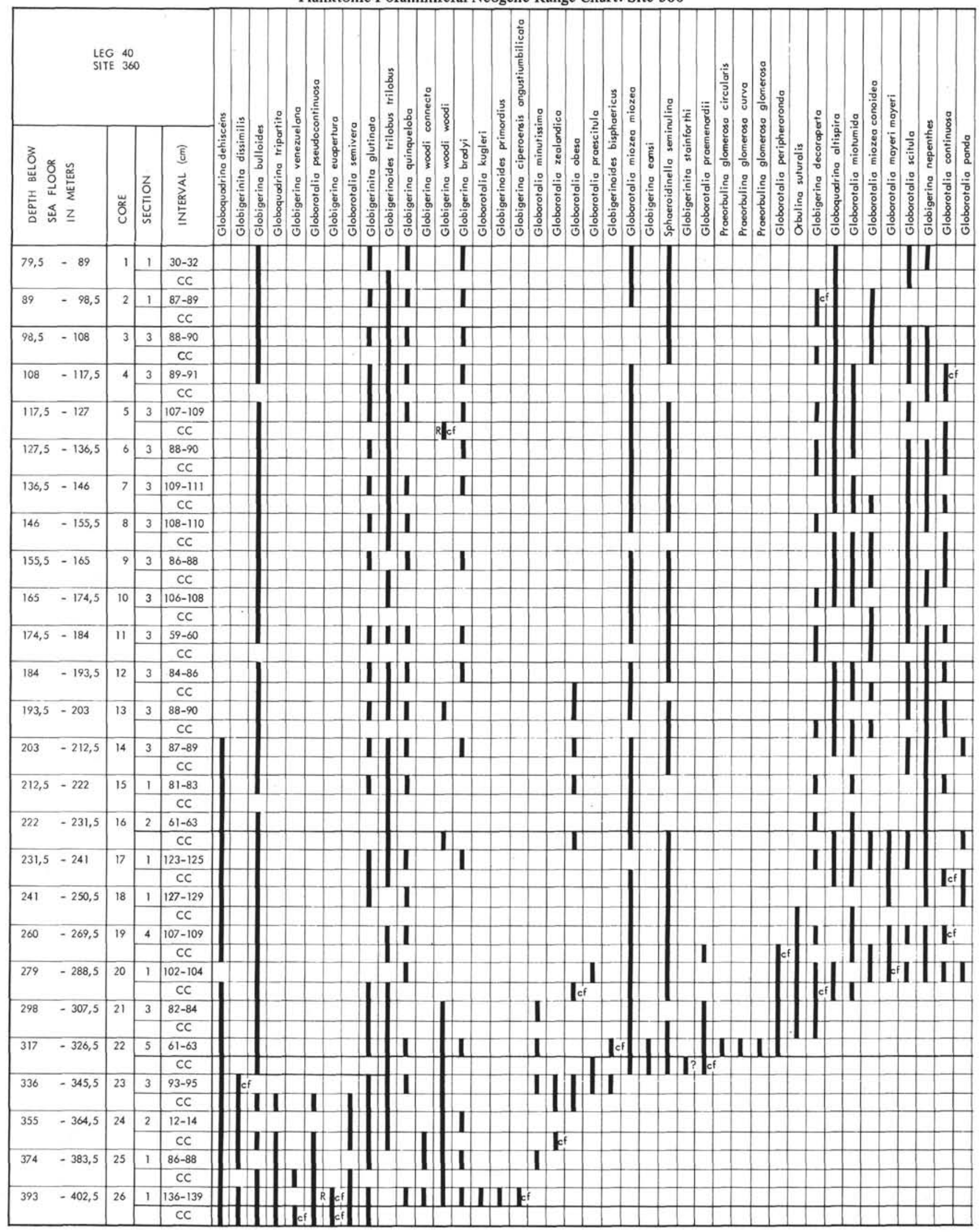


TABLE 1 - Continued

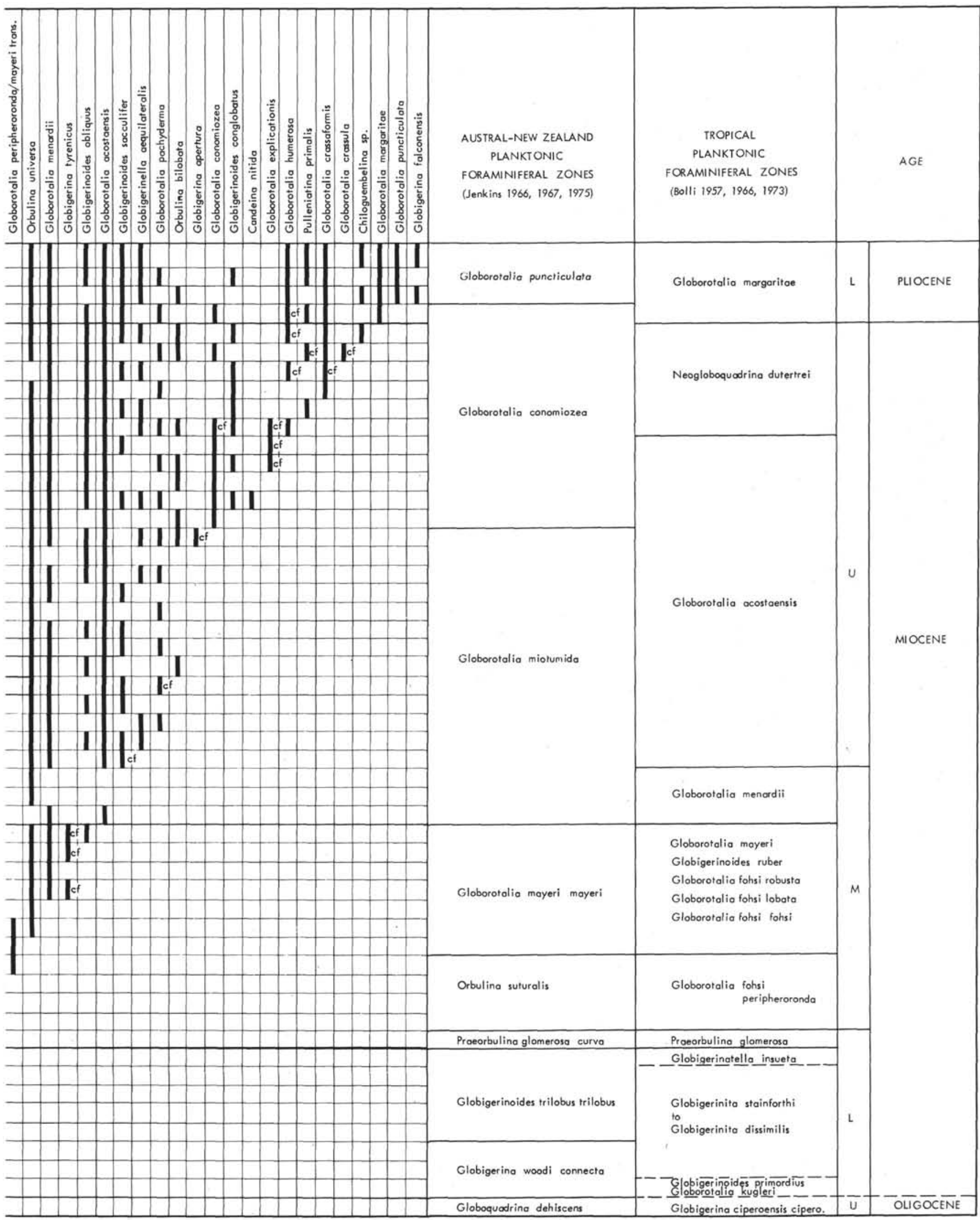


TABLE 2

Planktonic Foraminiferal Neogene Range Chart: Site 362

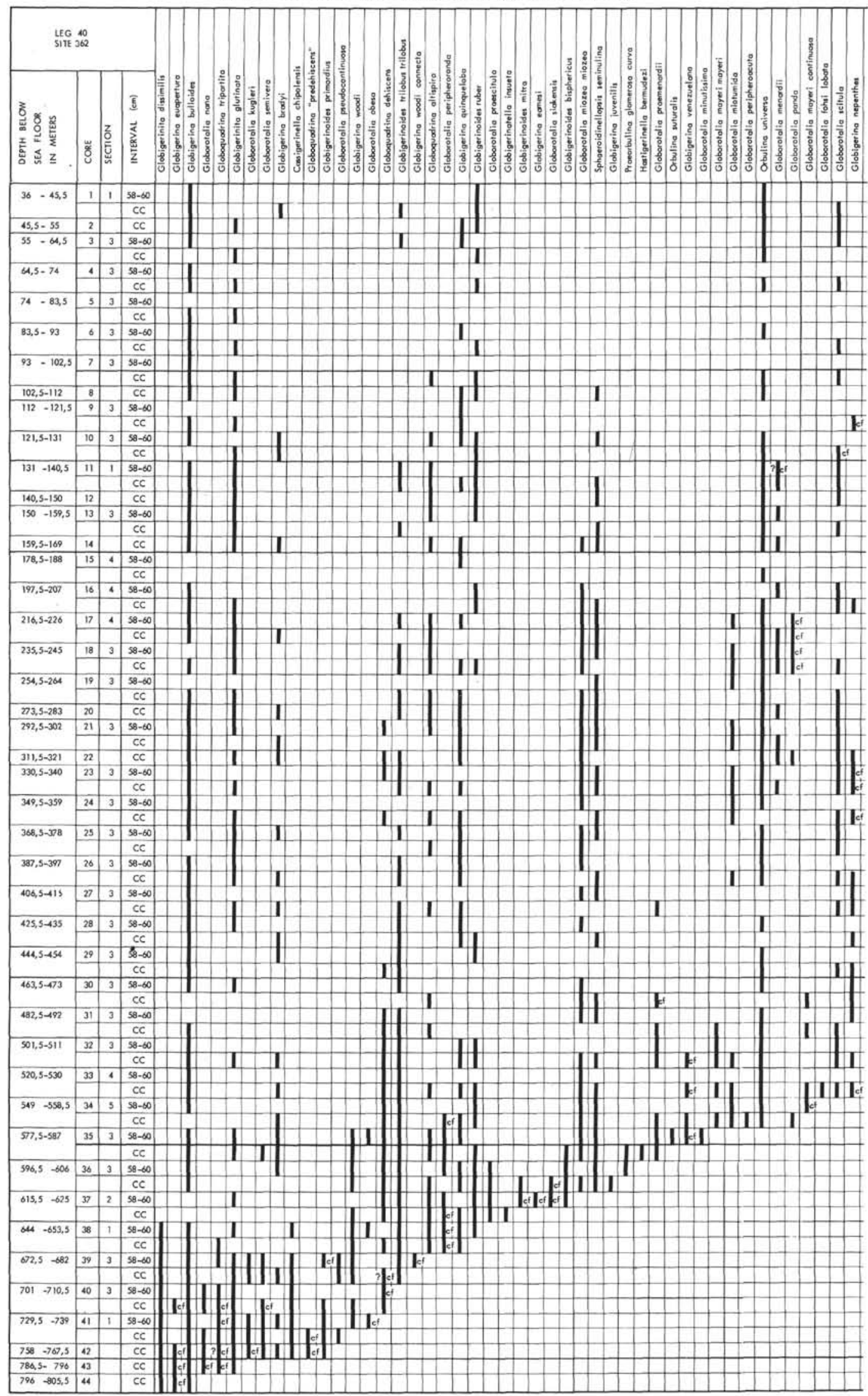


TABLE 2 - Continued

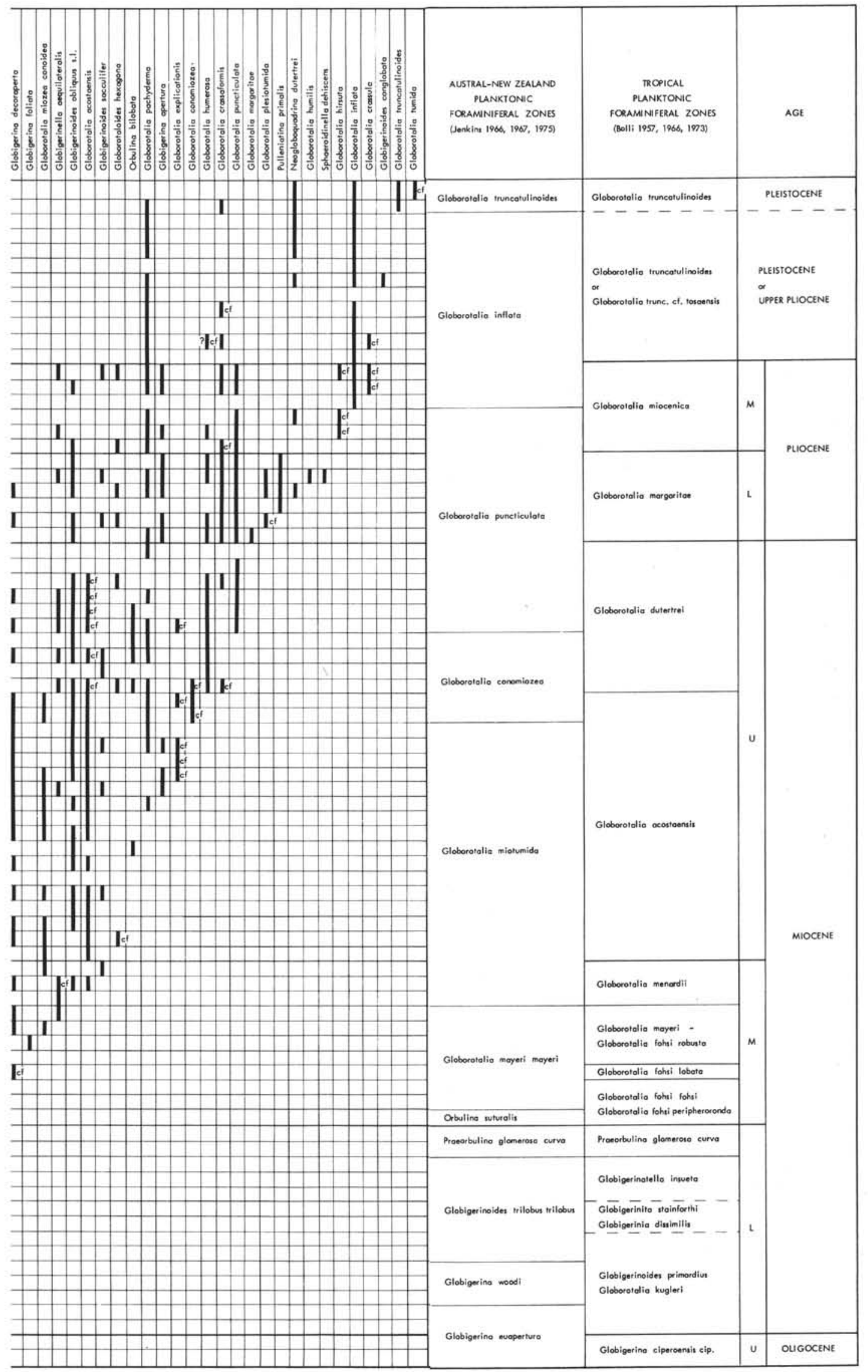


exilis Blow, $G$. miocenica Palmer, and $G$. multicamerata Cushman and Jarvis from the lower to middle Pliocene.

An important part of the fauna at both sites was the continued presence of Globigerina bulloides d'Orbigny and Globigerina quinqueloba Natland which are both restricted to transitional and cooler waters in the present day oceans (Bé and Toderlund, 1971).

Further in this report the faunas are briefly compared with the Neogene faunas of New Zealand, Australia, and those recorded on DSDP Leg 29 south of these two countries; the zones established there have been used on Leg 40 (Table 3). The forecast that the Cenozoic zonal scheme established in the Australian and New Zealand region would be applicable to other regions of the Southern Hemisphere (Jenkins, 1973) appears to be supported by the results from Leg 40 .

\section{COMPARISON OF FAUNAS FROM SITES 360 AND 362}

\section{Lower Miocene}

Diversity: Species diversity at Site 360 is 18 in the Globigerina woodi connecta Zone and 22 in the Globigerinoides trilobus trilobus Zone as compared with 14 in the Globigerina woodi woodi Zone and 28 in the Globigerinoides trilobus trilobus Zone at Site 362.

Faunas: Globorotalia zealandica Hornibrook, present only at Site 360 , is possibly the only species found which was restricted to the cooler Austral waters, previously recorded from southeastern Australia (Jenkins, 1960), New Zealand (Jenkins, 1971), and at Sites 279 and 281 DSDP Leg 29 south of New Zealand and Australia (Jenkins, 1975).

TABLE 3

Planktonic Foraminiferal Zones Showing Zonal Boundary Markers

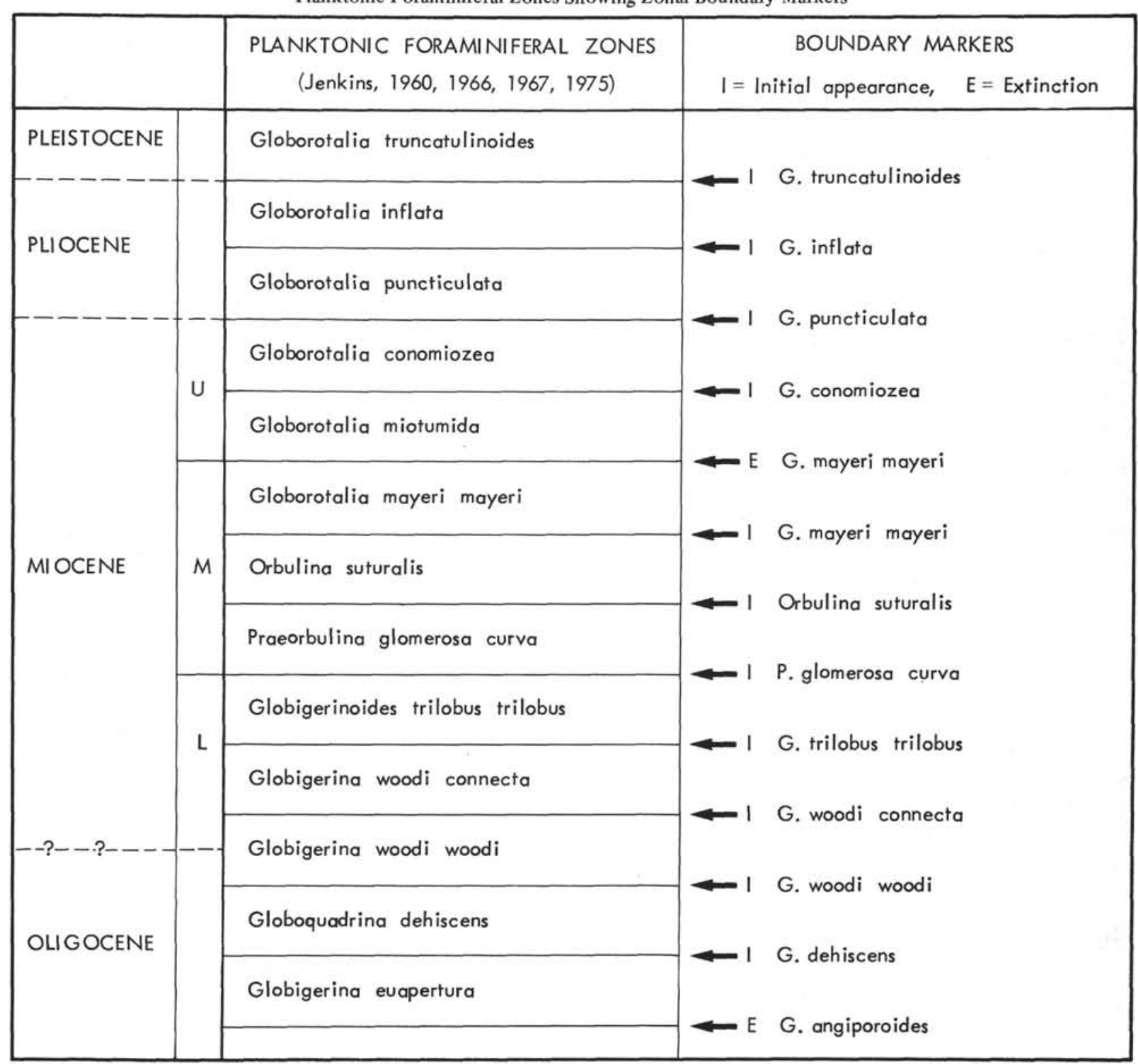


Globorotalia kugleri Bolli is restricted to the Globigerina woodi connecta Zone at Site 360 , but has a longer range, from the Globigerina woodi woodi Zone into the lower part of the Globigerinoides trilobus trilobus Zone at Site 362. Globigerinita dissimilis (Cushman and Bermudez) became extinct in the Globigerinoides trilobus trilobus Zone at both sites at a similar level to that at DSDP Leg 29 Site 279 south of New Zealand, but all these are stratigraphically later than its extinction in the Globigerina woodi connecta Zone in New Zealand (Jenkins, 1971).

The following species are present in the Neogene only at Site 362 and could be regarded as warmer water indicators: Cassigerinella chipolensis (Cushman and Ponton), Globoquadrina altispira (Cushman and Jarvis), Globigerinoides ruber (d'Orbigny), Globigerinatella insueta Cushman and Stainforth, and Globigerinoides mitra Todd. However, the low numbers of specimens of these species plus the earlier extinction of Globigerinatella insueta in the Globigerinoides trilobus trilobus Zone (compared with its middle Miocene extinction after the initial appearance of Orbulina suturalis Bronnimann in Trinidad [Bolli, 1957]) are indications of deteriorating conditions, possibly cooling, which affected Site 362 .

The brief appearances of Globigerinatella insueta and Globigerinoides mitra in the upper part of the Globigerinoides trilobus trilobus Zone at Site 362 are linked to Site 360 by the similarly short ranging Globigerina eamesi Blow which survived a little longer at Site 360 into the Praeorbulina glomerosa curva Zone.

Globoquadrina dehiscens (Chapman, Parr, and Collins) made a much earlier appearance in the Globoquadrina dehiscens Zone at Site 360 as compared with its appearance in the Globigerina woodi woodi Zone at Site 362. This diachronous spread northwards of Globoquadrina dehiscens has already been noted in New Zealand and Trinidad (Jenkins, 1973).

In constrast to the New Zealand region, Globorotalia pseudocontinuosa Jenkins became extinct earlier at the two sites in the Globigerinoides trilobus trilobus Zone as opposed to its extinction in the middle Miocene Orbulina suturalis Zone.

Biostratigraphic markers: Important markers include the initial appearances of Globigerinoides trilobus trilobus (Reuss), Globorotalia praescitula Blow, and Globorotalia miozea Finlay in the Globigerinoides trilobus trilobus Zone; the extinction of Globoquadrina tripartita (Koch) also occurs in this zone.

\section{Middle Miocene}

Diversity: Species diversity in the three zones at Site 360 is 16 in the Praeorbulina glomerosa curva Zone, 24 in the Orbulina suturalis Zone, and 28 in the Globorotalia mayeri mayeri Zone, as compared with 18, 16 , and 26 in these zones at Site 362. The lower diversity in the more northern site in the upper two zones is unexpected, but it may be partly explained in that the Orbulina suturalis Zone appears to be much thinner at Site 362 , with a possibility of a hiatus.

Faunas: Warmer water species occur at Site 362 which are not present at the more southern Site 360, and these include Hastigerinella bermudezi Bolli, Globorotalia peripheroacuta Banner and Blow, and $G$. fohsi lobata Bermudez. Site 360 was south of the southern limit of keeled $G$. fohsi lineage taxa (Jenkins, 1965) with only brief incursions of a few keeled specimens at Site 362.

Globorotalia peripheroronda Banner and Blow appeared earlier in the more northern Site 362 in the Globigerinoides trilobus trilobus Zone, at a similar stratigraphic level to that recorded in Trinidad (Bolli, 1957). By contrast it appeared later in the middle Miocene Praeorbulina glomerosa curva Zone at Site 360, at the same stratigraphic level as in New Zealand (Jenkins, 1967).

Transition populations exist between Globorotalia peripheroronda and Globorotalia mayeri Cushman and Ellisor in the upper Orbulina suturalis Zone and lower part of the Globorotalia mayeri Zone. A similar transition has been recorded in southeast Australia and New Zealand (Jenkins, 1960, 1971), but this transition was not detected in the faunas of Site 362 .

The comparatively late appearance of Globigerinoides obliquus in the lower part of the Globorotalia miotumida Zone at Site 362 and in the upper part of the Globorotalia mayeri mayeri Zone in Site 360 and of Globigerinoides sacculifer only in the Globorotalia miotumida Zone at Site 362 suggests a possible warming at this interval with a greater temperature increase at Site 362 . This is apparently contradicted by the initial appearance of Globorotalia pachyderma (Ehrenberg) at both sites in the upper Miocene Globorotalia miotumida Zone, but could be explained by mixing of two water masses.

Biostratigraphic markers: Of importance are the initial appearances of taxa of the Orbulina lineage at Site 362 and those of the Globorotalia mayeri lineage at Site 360 .

\section{Upper Miocene}

Diversity: Species diversity in the two sites is not greatly different with 27 in the Globorotalia miotumida Zone and 32 in the Globorotalia conomiozea Zone at Site 360 compared with 29 and 28 at Site 362 . The slight diversity reduction in the higher zone at Site 362 is unexplained.

Faunas: There is an overlap in the ranges of Globorotalia obesa Bolli and Globigerinella aequilateralis Cushman at Site 360 in the Globorotalia miotumida Zone which was not recorded at Site 362. Globoquadrina dehiscens became extinct much earlier at Site 360 in the lower part of the Globorotalia miotumida Zone as compared with its extinction in the lower part of Globorotalia conomiozea Zone at Site 362. This is consistent with the view that Globoquadrina dehiscens became extinct earlier in the higher latitudes in the Southern Hemisphere. Globigerinoides obliquus made its initial appearance in the uppermost part of the Globorotalia mayeri Zone at Site 360, but only in the upper lower part of the Globorotalia miotumida Zone at Site 362. Globigerinoides sacculifer (Brady) made its late initial appearance at both sites in the lower part of the Globorotalia miotumida Zone and Globigerina apertura 
Cushman occurred only in the upper part of the Globorotalia miotumida Zone at both sites. Globorotalia margaritae is recorded from the upper part of the Globorotalia conomiozea Zone ranging into the lower part of the Globorotalia puncticulata Zone at Site 360 but is only recorded in one sample in the Globorotalia puncticulata Zone at Site 362.

Biostratigraphic markers: The initial appearance of Globorotalia acostaensis is recorded at both sites in the lower part of the Globorotalia miotumida Zone; the initial appearance of sinistrally coiled Pulleniatina primalis Banner and Blow is recorded in the middle part of the Globorotalia conomiozea Zone at Site 360; and the initial appearance of Globorotalia crassaformis (Galloway and Wissler) occurs at both sites in the Globorotalia conomiozea Zone.

\section{Pliocene-Pleistocene}

Faunas: Pulleniatina primalis has a short range in the upper part of the Globorotalia puncticulata Zone at Site 362 but without its descendant species in the Pliocene, whereas at Site 360 it ranged from the upper part of the Globorotalia conomiozea Zone into the lower part of the Globorotalia puncticulata Zone.

One of the significant series of events in the Pliocene was the extinction of the larger keeled Globorotalia at Site 362 , namely $G$. miozea, G. miotumida Jenkins, and G. menardii (d'Orbigny). Progressive extinctions of taxa occurred, with both Globigerinoides obliquus Bolli and G. sacculifer (Brady) becoming extinct in the lower part of the Globorotalia inflata Zone at Site 362.

The Pleistocene species in Core 1 of Site 362 is consistent with the Recent transition fauna recorded by Bé and Toderlund (1971).

Biostratigraphic markers: Orbulina bilobata (d'Orbigny) became extinct in the lower part of the Globorotalia puncticulata Zone at both sites and is consistent with the extinction level recorded by Parker (1967) in the Indo-Pacific. A marked horizon of extinction occurred in the lower part of the Globorotalia inflata Zone at Site 362 with the extinctions of Globorotalia hirsuta (d'Orbigny), G. puncticulata (Deshays), Globigerina apertura .Cushman. Globigerinella aequilateralis Cushman, Globorotaloides hexagona (Natland), Globigerinoides sacculifer (Brady), and Globoquadrina altispira (Cushman and Jarvis). Such a level could be explained either by a radical change in the fauna or a hiatus.

\section{SYSTEMATICS}

Selected species are illustrated to show the interrelationship of the cooler Austral and the warmer water tropical forms. Comments are limited to a few observations on some important taxa:

\section{Globigerina woodi connecta Jenkins} (Plate 1, Figures 1-5)

The subspecies is illustrated to show its morphological affinity with Globigerina woodi Jenkins (pl. 1, fig. 6, 7) and with Globigerinoides trilobus (Reuss) (pl. 1, fig. 8,9) which is regarded as its direct descendant (Jenkins, 1964). Not only is there close similarity of the general test shape of Globigerina woodi connecta and Globigerinoides trilobus, but it is also true for the wall structure of both taxa (pl. I, fig. 5,8); specimens of Globigerinoides trilobus were taken from a stratigraphically low position in the Globigerinoides trilobus trilobus Zone.

\section{Globorotalia conomiozea Kennett}

(Plate 2, Figures 15-17)

The illustrated specimens are thick-walled varieties and consequently appear slightly different from the holotype; these are probably deeper water ecophenotypes similar to forms already noted for other keeled Globorotalia including G. truncatulinoides.

\section{Globorotalia miotumida Jenkins}

(Plate 2, Figures 6-8)

The type population from southeastern Australia were relatively thin walled (Jenkins, 1960) and since then observations have been made linking the species to Globorotalia miozea conoidea Walters (Jenkins, 1971). Specimens (Plate 2, Figures 6-8) have been chosen to illustrate the intermediate morphology and should be compared with the illustrations of $G$. miozea conoidea (Plate 2, Figures 12-14).

\section{Globorotalia mayeri mayeri Cushman and Ellisor} (Plate 1, Figures 20-22)

Specimens have been chosen from the lowermost sample in the Globorotalia mayeri mayeri Zone to illustrate the close morphological affinity of the subspecies with its immediate ancestor $G$. peripheroronda (e.g., recurved sutures).

\section{Globorotalia panda Jenkins}

(Plate 2, Figures 3-5)

At both sites $G$. panda is recorded sporadically in the middle Miocene to lower Pliocene (Tables I, 2). A remarkable case of homeomorphy exists between $G$. panda and Globorotalia margaritae Bolli (Plate 3, Figures 13-15).

Wall structure: (1) The pustular wall ornamentation of Globigerinella aequilateralis is illustrated in Plate 3, Figure 7. (2) There is a strong similarity between the wall structures of Globigerinoides obliquus (Plate 3, Figures 1,3) and G. sacculifer (Plate 3, Figure 5): small holes exist along the ridges of the hexagons surrounding the pores in both species. (3) The thickening of the wall ornamentation and lip nearly obscures all pores in Globorotalia pachyderma (Plate I, Figure 13).

\section{CONCLUSIONS}

Faunas: Neogene planktonic foraminifers from Sites 360 and 362 are similar to the faunas described from southeastern Australia and New Zealand (Jenkins, $1960,1966,1967)$ where the dominant Austral faunas were occasionally invaded by exotic species migrating from the northern waters. There is a gradual extinction of various species in the Pliocene, consistent with established evidence of a deterioration in climate towards the Pleistocene. The lack of some species and scarcity of other tropical stratigraphic markers makes it difficult to apply some of the tropical zones, but an attempt at correlating the Austral cooler water zones with the tropical zones of Bolli (1957 et seq.) has been undertaken (Tables 1,2).

Although there are marked contrasts in the faunas from the two sites it is nevertheless difficult to detect north-south pulsations. What can be detected are possible warm water invasions followed by cooling at Site 362 causing premature extinctions not seen in known warm water regions. For example, such an explanation could apply to the brief appearance of Globigerinella insueta and Globigerinoides mitra in the upper part of the Globigerinoides trilobus trilobus Zone. Similarly Sphaeroidinella dehiscens appeared briefly in the lower Pliocene Globorotalia puncticulata Zone, but the differences between the two sites are best illustrated by plotting the range of selected taxa at the two sites (Figure 2). This demonstrates the possible interaction 


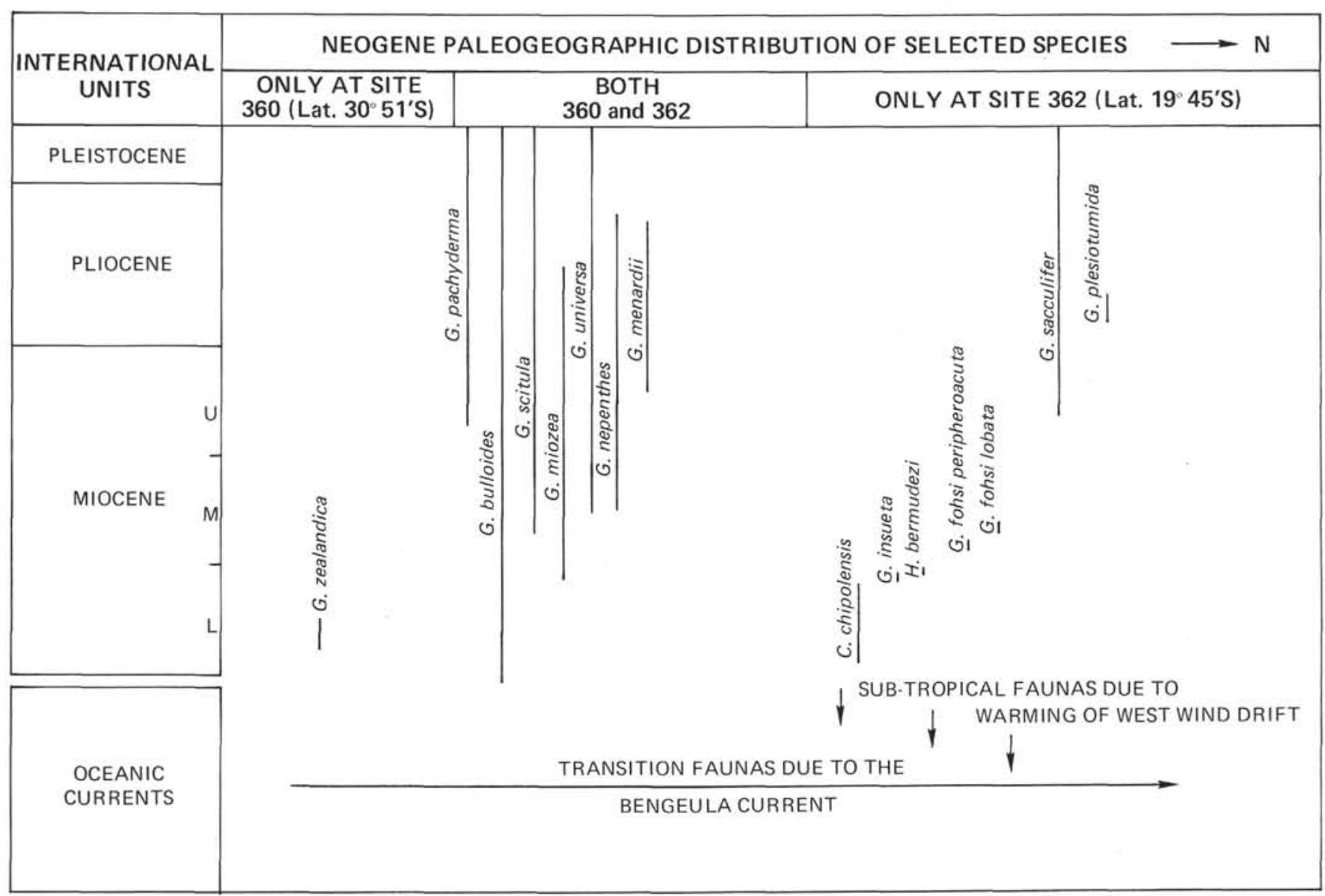

Figure 2. General ranges of selected species to illustrate the possible faunal influences during the Neogene at Sites 360 and 362: the Benguela current becoming progressively colder towards the Upper Neogene.

of the transition and subtropical fauna due to the effects of the cold Benguela current and the warmer west-wind-drift (see Sverdrup et al, 1942).

The difference in the oceanic regime as compared with the Pacific New Zealand region is exemplified by the changing species diversity in the Neogene. Whereas the maximum species number was recorded in the middle Miocene Praeorbulina glomerosa curva Zone in New Zealand, there was a relative low at both Sites 360 and 362 in this zone. However, the maximum number of species in the Pliocene Globorotalia puncticulata Zone at Sites 360 and 362 was reflected in the New Zealand lower Pliocene species number (Jenkins, 1968).

Zones: The zones established in Australia and New Zealand (Jenkins, 1960, 1966, 1967) and later extended to the Southern Ocean on DSDP Leg 29 (Jenkins, 1975) are applicable to Leg 40 Sites 360 and 362 where the same zonal markers were utilized (Table 3 ). The only difficulty experienced in zonal identification was the apparent lack of two zones:

1) The lower Miocene Globigerina woodi woodi Zone at Site 360 possibly exists in the unsampled sequence between core Samples 26-1, 136-139 cm and 26, CC. Alternatively, the zone may be missing because of a hiatus.

2) The Globigerina woodi connecta Zone was not recognized in the lower Miocene of Site 362 because of the poor development of the zonal species. It is concluded that this zone is probably equivalent to the upper part of the Globigerina woodi woodi Zone at Site 362 (Table 3).

The Orbulina suturalis Zone recorded in Cores 20 and 21 at Site 360 was only identified in one sample (35-3, $58-60 \mathrm{~cm}$ ) at Site 362 . This thinning could be explained by differences in the rates of sedimentation at the two sites, but because Praeorbulina glomerosa glomerosa (Blow), P. glomerosa circularis (Blow), and $P$. glomerosa circularis (Blow) were not recorded at 362 , it is possible that the lower part of the Orbulina suturalis Zone is missing because of a hiatus.

\section{ACKNOWLEDGMENTS}

I wish to thank Professor H.M. Bolli for the opportunity of examining the faunas from Sites 360 and 362 and for arranging research facilities at Zürich where the SEM photographs were taken by Mr. H. Franz. Preliminary work on the samples was undertaken at the University of Canterbury, Christchurch, New Zealand, and later at the University College of Wales, Aberystwyth.

\section{REFERENCES}

Bé, A.W.H. and Toderlund, D.S., 1971. Distribution and ecology of living planktonic foraminifera in surface water of the Atlantic and Pacific Oceans: Micropaleontology of oceans: (Eds.), Funnell, B.M. and Riedel, W.R., (Cambridge Univ. Press), p. 105-149. 
Bolli, H.M., 1957. Planktonic foraminifera from the Oligocene-Miocene Cipero and Lengua formations of Trinidad B.W.I.: Bull. U.S. Nat. Mus., v. 215, p. 97-123.

Jenkins, D.G., 1960. Planktonic foraminifera from the Lakes Entrance oil shaft, Victoria, Australia: Micropaleontology, v. 6., p. 345-371.

1964. A new planktonic foraminiferal subspecies from the Australasian lower Miocene: Micropaleontology, v. 10, p. 72 .

1965. Planktonic foraminifera and Tertiary intercontinental correlation: Micropaleontology, v. 11, p. 265-277.

1966. Planktonic foraminiferal zones and new taxa from the Danian to Lower Miocene of New Zealand: New Zealand J. Geol. Geophys., v. 8, p. 1088-1125. 1967. Planktonic foraminiferal zones and new taxa from the Lower Miocene to Pleistocene of New Zealand: New Zealand J. Geol. Geophys. v. 10, p. 1064-1078.

1968. Variation in the numbers of species and subspecies of planktonic foraminifera as an indicator of New Zealand Cenozoic paleotemperatures: Paleogeog., Palaeoclimat., Paleoecol., v. 5., p. 309-313.

, 1971. Cenozoic planktonic foraminifera of New Zealand: New Zealand Geol. Surv. Paleontol., Bull. 42, p. $1-278$.
1973. The present status and future progress in the study of Cenozoic planktonic foraminifera: Rev. Espan. Micropaleontologia, v. 5., p. 133-146.

, 1975. Cenozoic planktonic foraminiferal biostratigraphy of the southwestern Pacific and Tasman Sea, DSDP Leg 29. In Kennett, J.P., Houtz, R.E., et al., Initial Reports of the Deep Sea Drilling Project, Volume 29: Washington (U.S. Government Printing Office) p. 449467.

Parker, F.L., 1967. Late Tertiary biostratigraphy (planktonic foraminifera) of tropical Indo-Pacific deep-sea cores: Am. Paleontol., Bull., v. 52, p. 115-208.

Sverdrup, H.W., Johnson, M.W., and Fleming, R.H., 1942. The oceans, their physics, chemistry and general biology: New York (Prentice Hall), p. 1-1060.

\section{PLATES}

Each figure is of a different specimen, unless otherwise stated. The specimens illustrated on Plates 13 are deposited in the Museum of Natural History, Basel, Switzerland, under the numbers C 33321-33369. 



\section{PLATE 1}

Figures 1-5 Globigerina woodi connecta Jenkins; Sample 360$25-1,80-88 \mathrm{~cm}$; lower Miocene, Globorotalia woodi connecta Zone.

1. Side view, $\times 100$; C 33321 .

2. Umbilical view, $\times 100 ; \mathrm{C} 33322$.

3. Spiral view, $\times 100 ; C 33323$.

4. Side view, $\times 100$; C 33324 .

5. Wall structure of Figure $4, \times 1000$.

Figures 6,7 Globigerina woodi Jenkins; Sample 362-36, CC; lower Miocene, Globigerinoides trilobus trilobus Zone.

6. Umbilical view, $\times 100$; C 33325 .

7. Wall structure of Figure $6, \times 1000$.

Figures 8,9 Globigerinoides trilobus (Reuss); Sample 362-37, CC; lower Miocene, Globigerinoides trilobus trilobus Zone.

8. Umbilical view, $\times 100$; C 33326 .

9. Wall structure of $8, \times 1000$.

Figures 10-13 Globorotalia pachyderma (Ehrenberg); Sample 362-20, CC; upper Miocene, Globorotalia conomiozea Zone.

10. Side view, $\times 100$; C 33327.

11. Spiral view, $\times 100$; C 33328 .

12. Umbilical view, $\times 100$; C 33329.

13. Wall structure of $12, \times 500$.

Figures 14-16 Globorotalia pseudocontinuosa Jenkins; Sample 360-25-1, 86-88 cm; lower Miocene, Globigerina woodi connecta Zone.

14. Side view, $\times 100$; C 33330 .

15. Spiral view, $\times 100$; C 33331 .

16. Umbilical view, $\times 100$; C 33332 .

Figures 17-19 Globorotalia zealandica Hornibrook; Sample 36023-3, 93-95 cm; lower Miocene Globigerinoides trilobus trilobus Zone.

17. Side view, $\times 100 \mathrm{C} 33333$.

18. Umbilical view, $\times 100 \mathrm{C} 33334$.

19. Spiral view, $\times 100 \mathrm{C} 33335$.

Figures 20-22 Globorotalia mayeri Cushman and Ellisor; Sample 362-34, CC; middle Miocene, Globorotalia mayeri mayeri Zone.

20. Side view, $\times 100$; C 33336 .

21. Umbilical view, $\times 100$; C 33337 .

22. Spiral view, $\times 100 ;$ C 33338.

Figures 23, 24 Globorotalia semivera (Hornibrook); Sample 36024, CC; lower Miocene, Globigerinoides trilobus trilobus Zone.

23. Side view, $\times 100$; C 33339 .

24. Umbilical view, $\times 100$; C 33340 . 
PLATE 1

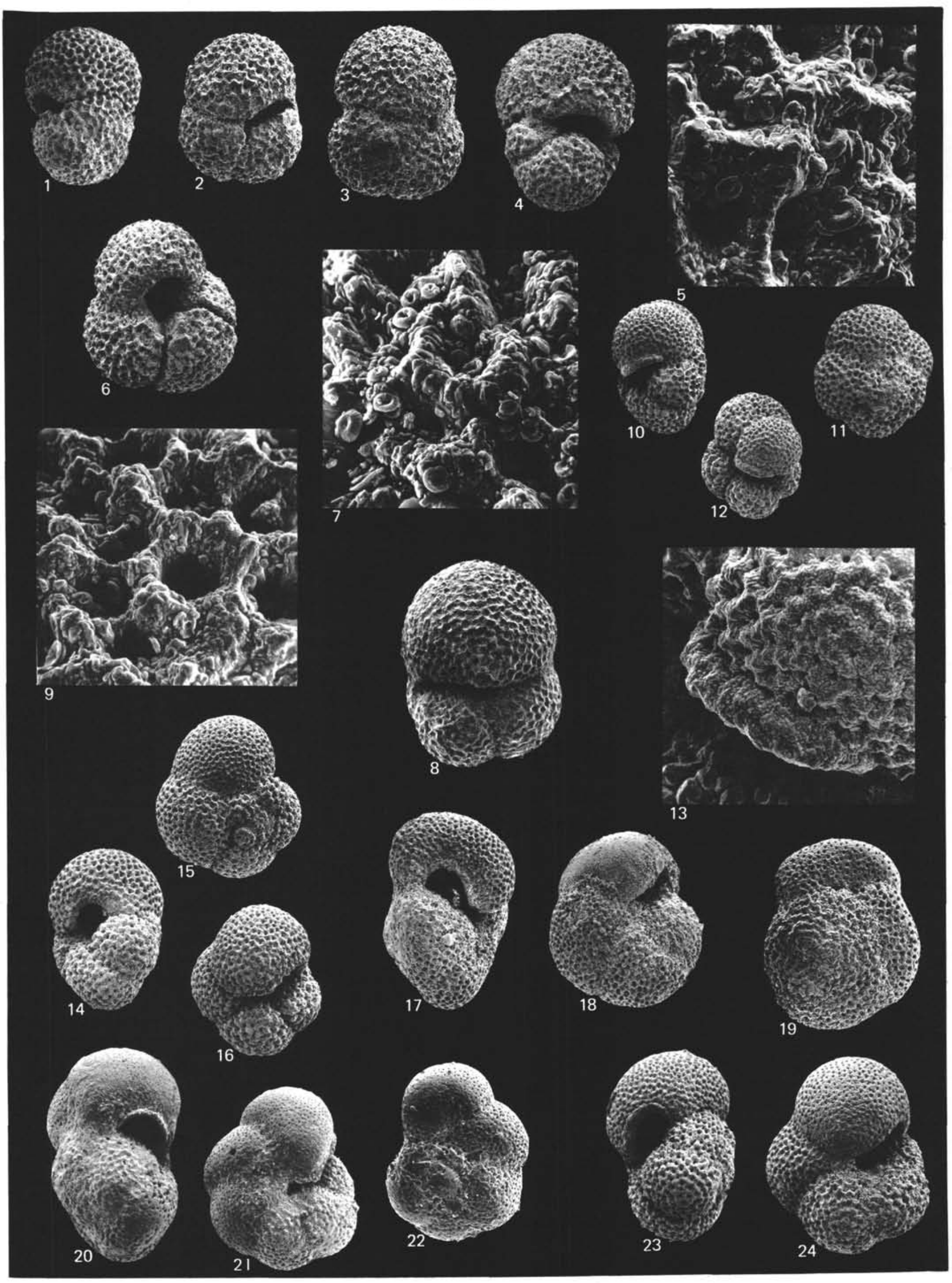


PLATE 2
Figures 1, $\quad$ Globorotalia puncticulata (Deshays); Sample $362-$ 13, CC; lower Pliocene, Globorotalia puncticulata Zone.

1. Side view, $\times 100 ;$ C 33341 .

2. Umbilical view, $\times 100$; C 33342 .

Figures 3-5 Globorotalia panda Jenkins; Sample 360-17, CC; middle Miocene, Globorotalia mayeri mayeri Zone.

3. Side view, $\times 100$; C 33343 .

4. Umbilical view, $\times 100$; C 33344 .

5. Spiral view, $\times 100 ;$ C 33345 .

Figures 6-8 Globorotalia miotumida Jenkins; Sample 360-16, $\mathrm{CC}$; middle Miocene, Globorotalia mayeri mayeri Zone.

6. Side view, $\times 100$; C 33346 .

7. Umbilical view, $\times 100 ;$ C 33347 .

8. Spiral view, $\times 100 ;$ C 33348 .

Figures 9-11 Globorotalia miozea miozea Finlay; Sample 36236, CC; lower Miocene, Globorotalia trilobus trilobus Zone.

9. Side view, $\times 100$; C 33349 .

10. Umbilical view, $\times 100 ; C 33350$.

11. Spiral view, $\times 100$; C 33351 .

Figures 12-14 Globorotalia miozea conoidea Walters; Sample 362-27, CC; upper Miocene, Globorotalia miotumida Zone.

12. Side view, $\times 100$; C 33352 .

13. Umbilical view, $\times 100 ; C 33353$.

14. Spiral view, $\times 100$; C 33354 .

Figures 15-17 Globorotalia conomiozea Kennett; Sample 360-7, CC; upper Miocene, Globorotalia conomiozea Zone.

15. Side view, $\times 100$; C 33355 .

16. Umbilical view, $\times 100$; C 33356 .

17. Spiral view, $\times 100 ;$ C 33357 . 
PLATE 2

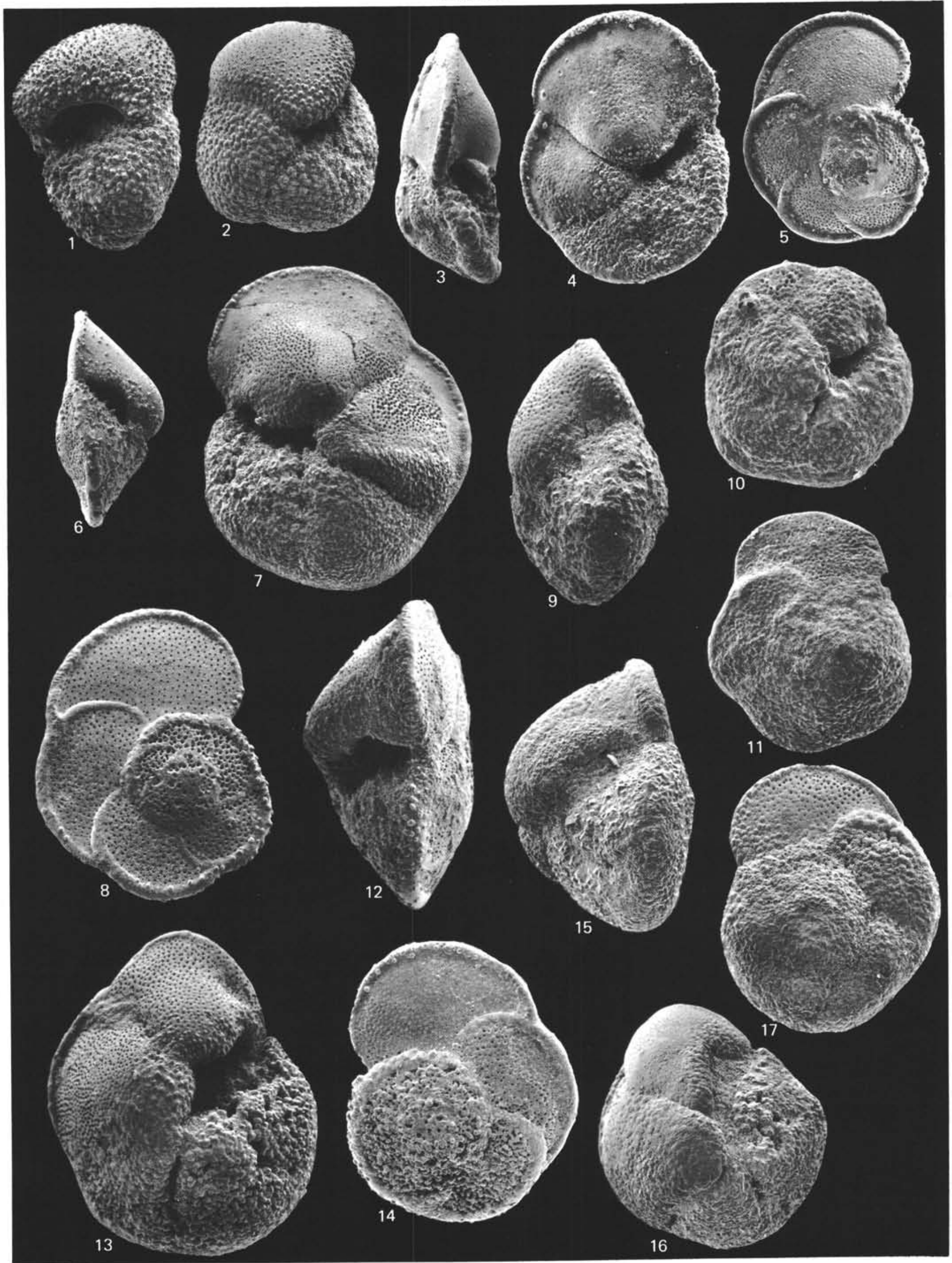


Figures 1-3 Globigerinoides obliquus Bolli; Sample 262-18, CC; upper Miocene, Globorotalia conomiozea Zone.

1. Detail of aperture and wall structure of Figure $2, \times 250$.

2. Umbilical view, $\times 100$; C 33358 .

3. Wall structure of Figure $2, \times 1000$.

Figures 4, 5 Globigerinoides sacculifer (Brady); Sample 362-13, CC; lower Pliocene, Globorotalia puncticulata Zone.

4. Umbilical view, $\times 100$; C 33359.

5. Wall structure, $\times 500$.

Figures 6,7 Globigerinella aequilateralis Cushman; Sample 360-1, CC; lower Pliocene, Globorotalia puncticulata Zone.

6. Side view, $\times 100$; C 33360 .

7. Wall structure of Figure $6, \times 750$.

Figure 8 Globorotalia menardii (d'Orbigny); Sample 362-18, $\mathrm{CC}$; upper Miocene, Globorotalia conomiozea Zone.

Umbilical view, $\times 40$; C 33361 .

Figures 9-11 Globorotalia fohsi lobata Bolli; Sample 362-33, CC; middle Miocene, Globorotalia mayeri mayeri Zone.

9. Side view, $\times 100$; C 33362 .

10. Umbilical view, $\times 100 ;$ C 33363 .

11. Spiral view, $\times 100$; C 33364 .

Figure 12 Globigerinatella insueta Cushman and Stainforth; Sample 362-37, CC; lower Miocene, Globigerinoides trilobus trilobus Zone.

Spiral view of juvenile, $\times 100$; C 33365 .

Figures 13-15 Globorotalia margaritae Bolli; Sample 362-14, CC; lower Pliocene, Globorotalia puncticulata Zone.

13. Umbilical view, $\times 100$; C 33366 .

14. Side view, $\times 100$; C 33367 .

15. Spiral view, $\times 100$; C 33368 .

Figure 16 Hastigerinella bermudezi Bolli; Sample 362-35, CC; middle Miocene, Praeorbulina glomerosa curva Zone.

Spiral view, $\times 100$; C 33369 . 
PLATE 3
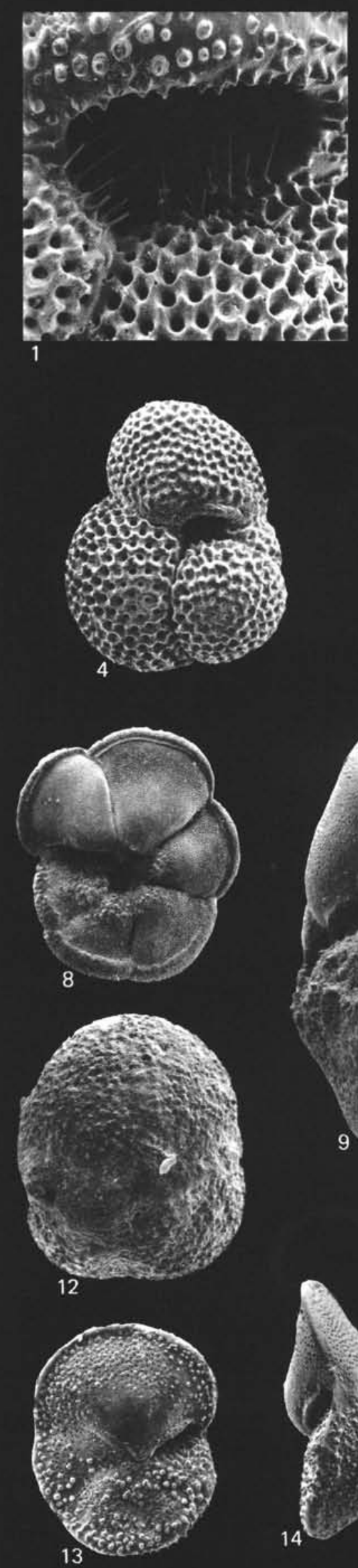
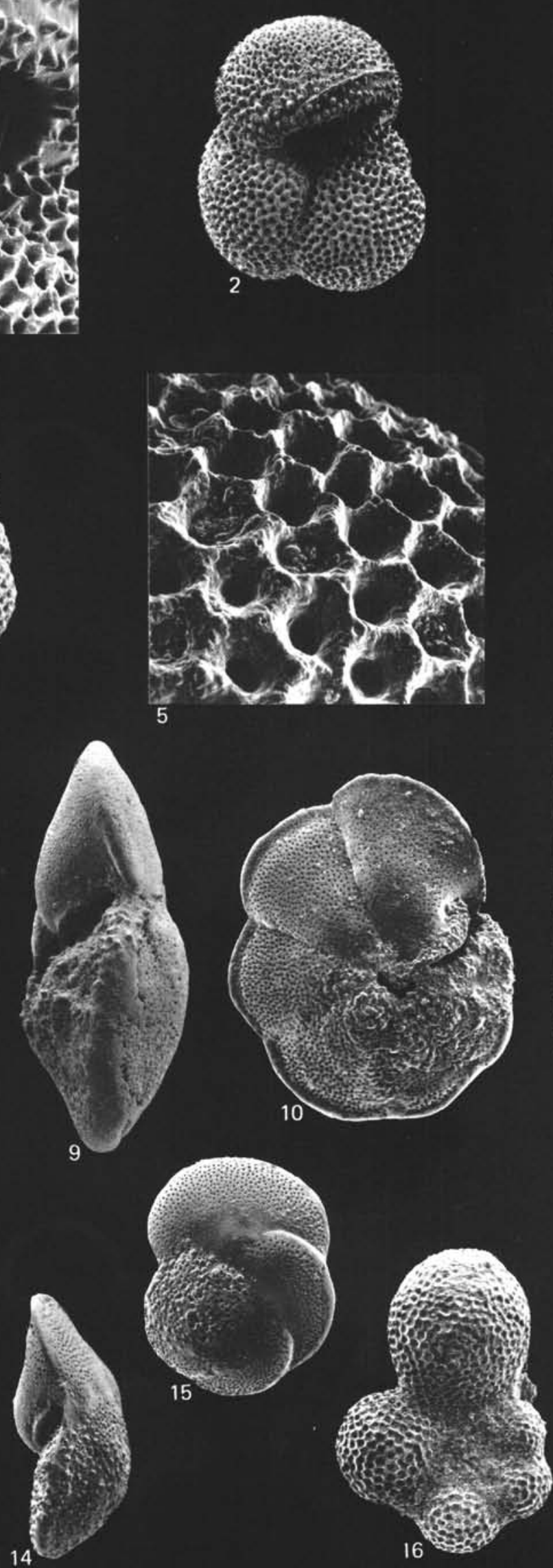
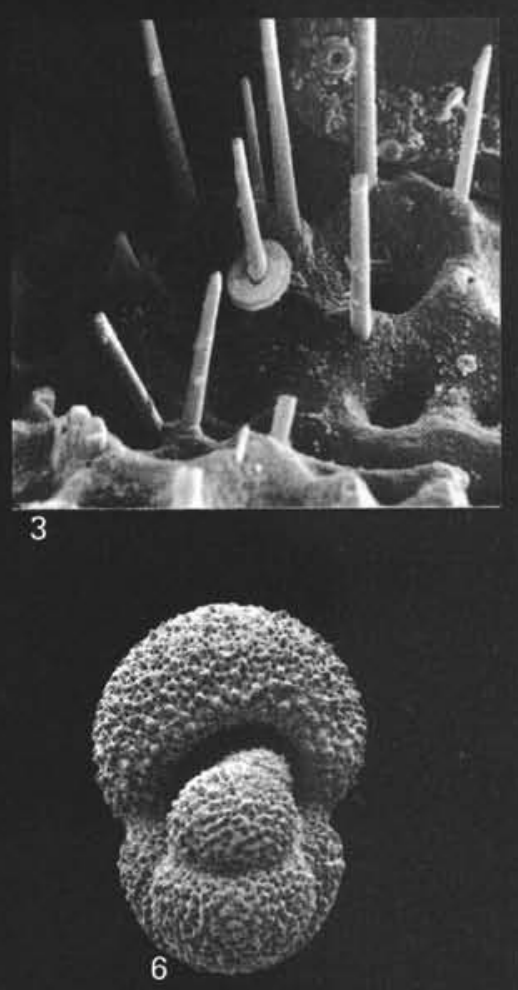

Jow of of 2 a rat

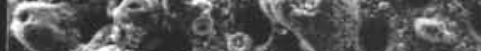
H 60 (s) aroing (1)

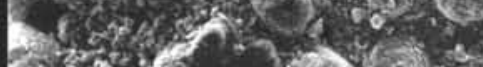

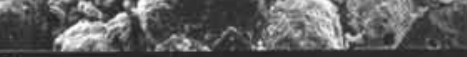

7

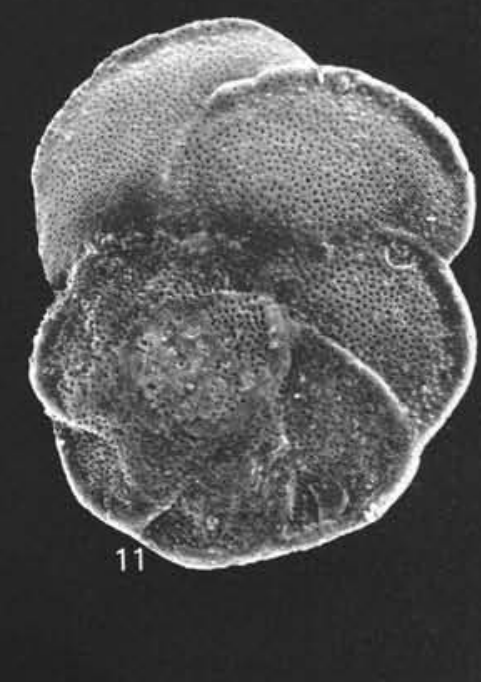

